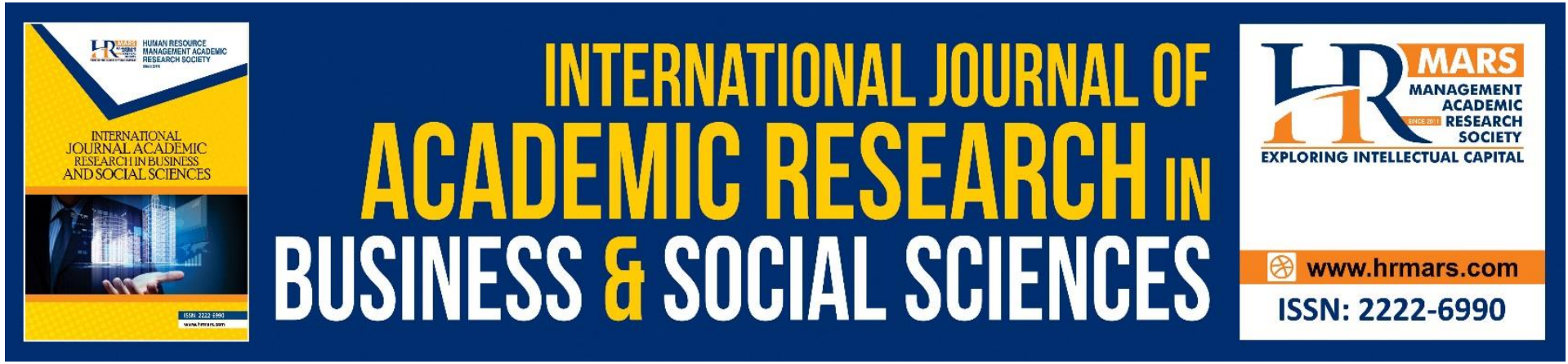

\title{
Influence of Strategy Formulation Practice on Performance of Milling Companies in Kenya
}

\author{
Faizah Cheptanui, Thomas A. Senaji
}

To Link this Article: http://dx.doi.org/10.6007/IJARBSS/v11-i8/10890

DOI:10.6007/IJARBSS/v11-i8/10890

Received: 09 June 2021, Revised: 12 July 2021, Accepted: 02 August 2021

Published Online: 26 August 2021

In-Text Citation: (Cheptanui \& Senaji, 2021)

To Cite this Article: Cheptanui, F., \& Senaji, T. A. (2021). Influence of Strategy Formulation Practice on Performance of Milling Companies in Kenya. International Journal of Academic Research in Business and Social Sciences, 11(8), 1648-1659.

Copyright: @ 2021 The Author(s)

Published by Human Resource Management Academic Research Society (www.hrmars.com)

This article is published under the Creative Commons Attribution (CC BY 4.0) license. Anyone may reproduce, distribute, translate and create derivative works of this article (for both commercial and non-commercial purposes), subject to full attribution to the original publication and authors. The full terms of this license may be seen at: $\underline{\text { http://creativecommons.org/licences/by/4.0/legalcode }}$

Vol. 11, No. 8, 2021, Pg. 1648 - 1659

Full Terms \& Conditions of access and use can be found at http://hrmars.com/index.php/pages/detail/publication-ethics 


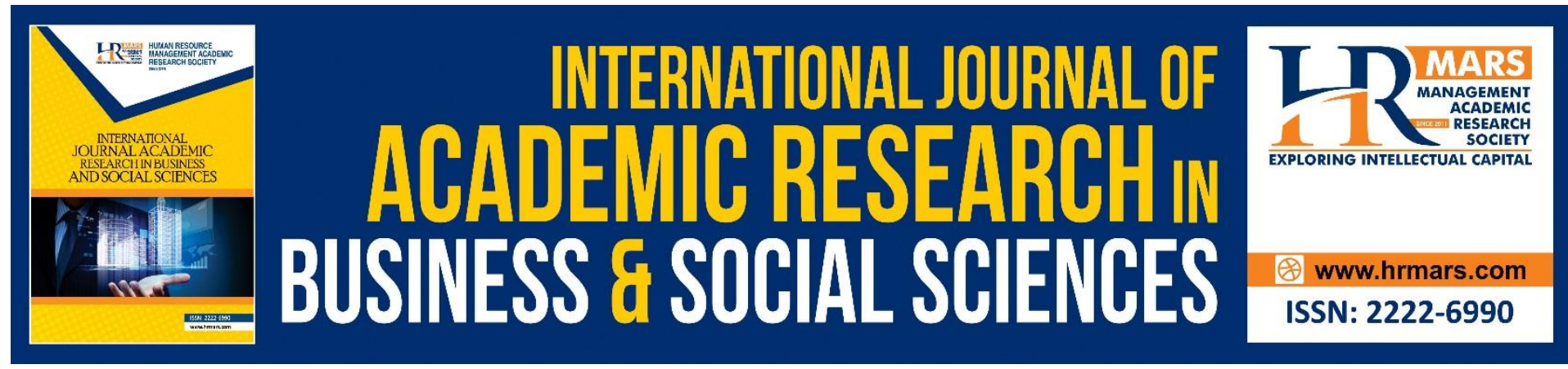

\title{
Influence of Strategy Formulation Practice on Performance of Milling Companies in Kenya
}

\author{
${ }^{1}$ Faizah Cheptanui ${ }^{2}$ Prof. Thomas A. Senaji \\ ${ }^{1}$ Jomo Kenyatta University of Agriculture and Technology, ${ }^{2}$ Lecturer Jomo Kenyatta \\ University of Agriculture and Technology
}

\begin{abstract}
The milling firms in Kenya have been facing challenges. There has been a growing demand of flour from, within and from outside the country from places such as Southern Sudan, Rwanda and Burundi. The study was guide by the following specific objective to determine the influence of strategy formulation practice. The study was informed by system theory. The study was guided by descriptive survey research design. The accessible population for this study was 11 administrators, 23 public service management employees, 19 finance employees, 15 economic planning employees, 35 procurement employees and 7 ICT employees. Sample size for the study were 86 respondents. The study applied the use of stratified random sampling technique. This study adopted questionnaires as its main data collection tool. Pre-testing of research instruments were achieved through pilot study in Dola limited company. The collected data was coded and entered into the Statistical Package for Social Sciences (SPSS) program. The study used descriptive statistics and inferential statistics. Descriptive statistics was done using frequency percentages, means and standard deviation of each variable. Correlation and regression was used to show the relationship between the dependent variable and the whole group of independent variables. The results of the study was presented using tables. The study found out that there was positive linear effect of strategy formulation practices on performance of milling companies in Kenya $\left(\beta_{1}=.210\right.$, $p=0.036<0.05)$. The study concluded that strategy formulation practices have a positive and a significant influence on performance of milling companies in Kenya. The firm as deliberately set its strategic direction in form of vision statement. Also, has deliberately set its strategic direction in form of mission statement. Also, internal environment analysis is a top priority activity at your firm. Finally, firm analyzes information about its external environment to understand their implications. The study recommends that milling firms should deliberately set its strategic direction in form of vision statement this will always ensure that internal environment analysis is a top priority activity at the firm. The milling firms should allocate adequate resources, involve stakeholders during strategy formulation, operationalize strategies and always communicate comprehensively to all stakeholders during strategy execution in order for them to realize performance.
\end{abstract}

Keywords: Formulation, Performance, Strategy, Milling Companies, Influence 


\section{Background of the Study}

Over the years, organizations focus on how they can effectively put into practice their strategies and goals/plans to accomplish their objectives in line with the direction of organizational mission and vision (Bolisani \& Bratianu, 2017). Strategic management has been touted as one of the effective management tools in strengthening organization performance through effective decision making and systematic strategic formulation and implementation. Although, strategic management was more prevalent in the private sector since the concept was first developed, the interest of using strategic management in the public sector has increased over the last decade (Joyce, 2015).

Strategy formulation practices are processes by which an organization chooses the most appropriate courses of action to achieve its defined goals (Reeves \& Haanaes, 2015). This process is essential to an organization's success, because it provides a framework for the actions that will lead to the anticipated results. Strategic plans should be communicated to all employees so that they are aware of the organization's objectives, mission, and purpose. Strategy formulation forces an organization to carefully look at the changing environment and to be prepared for the possible changes that may occur (Hanssens \& Pauwels, 2016).

In Malaysia, high-performing milling companies have HR professionals involved in the business at a strategic formulation (Yong \& Mohd-Yusoff, 2016). These strategic formulation professionals manage the culture, facilitate rapid change, are involved in the strategic decision making, and create market-driven connectivity of operations. Most notably, the strategic formulation accounted for 43 percent of the total impact on business performance in high-performing organizations. In this competency area, culture management, rapid change efforts, a business partner role, and a customer focus emerged as important factors for strategic formulation professionals, making their impact on their organizations' financial performance significant (Tripathi \& Jha, 2018).

In South Africa, lack of strategic planning process is a common experience among milling firms, with most managers/owners lacking strategic formulation skills (Afriyie, Duo \& Musah, 2018). This shows that strategic planning process in South Africa is still low and at early stages across most sectors. In Sub Saharan Africa, strategic planning process is still very low among milling firms in Uganda. In addition, small strategic planning process that is carried out among milling firms is still informal, with most firms still guided by the traditional way of operating business.

In Kenya, the rate of flour consumption is high, due to its rapidly increasing population and the fact that most of the local's staple food are made from flour. Agriculture being Kenya's main source of economic income makes the flour milling industry lustrous as the grains from the harvest has to be converted to flour (Mahulo, 2015). Kenya's highest grain production belongs to corn, followed by wheat and rice, with corn being the most preferred grain product staple food. One of the vital aspects of customer satisfaction in the Kenyan market is to meet customer's needs and expectations. Supply chain relationships play an important role in achieving the firm's goals (Saberi et al., 2019).

\section{Statement of the Problem}

The Kenyan manufacturing sector is considered as one of the key segments of the economy. In addition, the Kenyan vision 2030 blue print, one of the key pillars of the attainment of the objectives of the strategy is the need for the manufacturing sector to grow at the rate of 8 per cent over a period of 20 years. This can only be achieved if there is growth in the profits of the sector and this will depend upon identifying all the variables that can influence profit 
of a firm including the management of working capital. The inability of manufacturing firms to grow at the target rate is threatening the realization of vision Kenya's 2030 (Kamula, 2011). In Kenya, there have been efforts to improve performance in milling firms; this is aimed at achieving performance. The manufacturing sector has high, yet untapped, potential to contribute to employment and GDP growth. The milling firms in Kenya have been facing challenges. There has been a growing demand of flour from, within and from outside the country from places such as Southern Sudan, Rwanda and Burundi (Kenya National Bureau of Statistics, 2012). Performance is addressed in many researches but there are very few researches who explored its enhancing and betterment through strategy formulation. Strategy formulation involves coming up with the strategy in line with the vision and mission of the organization (Kan'goro, 2010). If a shortcoming is discovered against the mentioned outlined expected results, then the strategy can be modified or reformulated (Khan \& Huda, 2016). The study therefore sought to determine the influence of strategy formulation practice on performance of milling companies in Kenya.

\section{General Objective}

i. To determine the influence of strategy formulation practice on performance of milling companies in Kenya

\section{Research Questions}

i. What is the influence of strategy formulation practices on performance of milling companies in Kenya?

\section{Theoretical Framework \\ Systems Theory}

This theory was proposed in the 1940s by the biologist Ludwig and furthered by Ross Ashby, (2009). They emphasized that real systems are open to, and interact with their environments, and they can acquire qualitatively new properties through emergence, resulting in continual evolution. Rather than reducing an entity the properties of its parts or elements, systems theory focuses on the arrangement of and relations between the parts which connect them into a whole. Systems analysis developed independently of systems theory, applies systems principles to aid a decision-maker with problems of identifying, reconstructing, optimizing, and controlling a system while taking into account multiple objectives, constraints and resources. It aims to specify possible courses of action, together with their risks, costs and benefits.

People who claim to take a system approach probably have most in common with respect to assumptions pertaining to the level of explanation, specifically taking a holistic view rather than a reductionist view. Many writers in the past twenty years have discussed how reductionism has been taken too far. Nonetheless, reductionism is deeply ingrained in Western culture. Reductionism on the other hand is the assumption that an entity can be divided into its component parts and that a cumulative explanation of the parts and their relations fully explains the entity.

The systems approach is an external standard that measures effectiveness based on longterm growth or sustainability. Effective systems are characterized by a steady state that systems theorists call homeostasis in order to "avoid the static connotations of equilibrium and to bring out the dynamic, processual, potential-maintaining properties of basically unstable. If an organization is able to maintain homeostasis, which includes not just survival 
but also growth, then it is effective. This perspective is broader and more comprehensive than the goal-attainment approach because it is not limited to measuring effectiveness as meeting goals determined by powerful internal coalitions that may or may not be propitious for the whole organization.

Systems theory, however, is not without some shortcomings. The first shortcoming relates to measurement, and the second is the issue of whether the means by which an organization survives really matter. Robbins noted that one criticism of this approach is that its focus is on "the means necessary to achieve effectiveness rather than on organizational effectiveness itself. "Robbins (1990). Measuring the means, or process, of an organization can be very difficult when compared to measuring specific end goals of the goal-attainment approach.

\section{Empirical Review}

\section{Strategy Formulation Practices and Performance of Milling Companies}

Chen and Bowen, (2012) did a study to find out whether and how strategic management is employed in the Chinese manufacturing Firm, as well as to explore the main characteristics of the strategic management process in these firms. A significant amount of the senior managers in studied firm considers strategic management as an important mechanism for the development of their business strategies. All of the studied firms are employing strategic management techniques. However, the strategic management processes in these firm tend to be carried out in an informal and simpler pattern comparing to the conceptual model. The study however focused on the manufacturing firms in general while current study looks into milling firms.

Onijingin, (2017) did a study on Competitive dynamics and corporate performance of selected flour milling companies in Nigeria. The study adopted a survey research design. The findings revealed that there were significant relationships between Competitive Behaviour and Corporate Performance. It also revealed a significant moderating effect of Competitive Capability on the relationship between Competitive Behaviour and Corporate Performance. However, Competitive Capability did not significantly moderate the relationship between Product Offering and Corporate Performance. The study however was done in Nigeria while current study is done in Kenya.

Macharia (2014) did a study on strategic responses to environmental challenges by alliance ginneries Ltd in Tanzania. The study intended to identify the changes that have occurred in the flour milling industry, the challenges these changes pose to Unga and how the company has responded to them. For determining the responses to competition. Porter's five-force industry' model was adopted, that is, the entry' of new competitors, threat of substitute products, bargaining power of suppliers, bargaining power of buyers and the rivalry between existing competitors in the industry. The study found out that competition has really intensified in recent years and the company has adopted several strategies to respond to increased competition. These strategies include quality consistency, flexible pricing, product rationalization and branding.

Kinyua et al (2015) sought to determine the strategic planning practices adopted by large manufacturing firms operating in Kisumu, Kenya and their relationship to firm performance. Questionnaires were used as the main instruments for data collection. Respondents from all the firms studied indicated that their respective organizations practice strategic planning, have strategic departments and have formal documentation of vision and mission statements. A correlation of strategic planning practices and key indicators of overall firm performance showed a high positive correlation co-efficient. It was concluded that strategic 
planning practices have a positive impact on firm performance. The study however was done in Kisumu County while current study was done in Eldoret, Uasin Gishu County.

\section{Conceptual Framework}

The conceptual framework offers a diagrammatic illustration of the link between the independent variable's strategy formulation practices and the dependent variable of performance of milling firms. The independent variables are proposed to affect the dependent variables of the study.

\begin{tabular}{|c|c|}
\hline $\begin{array}{l}\text { Strategy Formulation practices } \\
\text { - Vision } \\
\text { - Mission } \\
\text { - Internal environment } \\
\text { - } \text { analysis } \\
\text { - External environment } \\
\text { analysis }\end{array}$ & $\begin{array}{l}\text { Organizational Performance } \\
\text { - } \quad \text { Financial targets } \\
\text { - } \quad \text { Learning and growth } \\
\text { - } \quad \text { Operational performance } \\
\text { - } \quad \text { Market based performance }\end{array}$ \\
\hline Independent Variables & dependent Variables \\
\hline
\end{tabular}

\section{Research Methodology Research Design}

This current study applied the use descriptive survey design with aim of determining the influence of strategy formulation practice on performance of milling companies in Kenya. Surveys provide a high level of general capability in representing a large population (Lohr, 2019). This is because the data being gathered possess a better description of the relative characteristics of the general population involved in the study. As compared to other methods of data gathering, surveys are able to extract data that are near to the exact attributes of the larger population (Chen, Mao \& Liu, 2014). This design is chosen because it is relatively quick and easy to conduct; data on all variables is only collected once. It is also good for descriptive analyses and for generating hypotheses.

\section{Target Population}

Population is a complete set of individuals, cases or subjects with some common observable characteristics (Mugenda and Mugenda, 2003). The study targeted all Milling Companies employees in Eldoret. These employees come from administration office, public service management department, finance department, economic planning department, procurement department and ICT department. The accessible population is the subset of the target population where the researcher draws a sample for the study can make the conclusion. Therefore, the accessible for this study were 11 administrators, 23 public service management employees, 19 finance employees, 15 economic planning employees, 35 procurement employees and 7 ICT employees. 
Table 1 Target Population

\begin{tabular}{ll}
\hline Departments & Population \\
\hline Administration & 11 \\
Public Service Management & 23 \\
Finance & 19 \\
Economic Planning & 15 \\
Procurement & 35 \\
ICT & 7 \\
Total & 110 \\
\hline
\end{tabular}

\section{Sample Size and Sampling Techniques}

Dick (2006) notes that the correct sample size in a study is dependent on factors such as the nature of the population to be studied, the purpose of the study, the number of variables in the study, the type of research design, the method of data analysis and the size of the accessible population. Sampling technique refers to a procedure of selecting a part of population on which research can be conducted, which ensures that conclusions from the study can be generalized to the entire population. The researcher obtained sample size using Yamane formulae (1967).

$$
n=\frac{N}{1+N(e)^{2}}
$$

Where $\mathrm{n}$ is the sample size required

$\mathrm{N}$ is the population size $=110$

$\mathrm{e}$ is the level of precision $=0.05$

$$
\begin{aligned}
& n=\frac{110}{1+110(0.05)^{2}} \\
& n=86
\end{aligned}
$$

Table 2 Sample Size

\begin{tabular}{lll}
\hline Target Group & Proportion & Sample Size \\
\hline Administration & $11 / 110 * 86$ & 9 \\
Public Service Management & $23 / 110 * 86$ & 18 \\
Finance & $19 / 110 * 86$ & 15 \\
Economic Planning & $15 / 110 * 86$ & 12 \\
Procurement & $35 / 110 * 86$ & 27 \\
ICT & $7 / 110 * 86$ & 5 \\
Total & $110 / 110 * 86$ & $\mathbf{8 6}$ \\
\hline
\end{tabular}

The study applied the use of stratified random sampling technique. The departments where the staffs were selected from the strata (administration office, public service management department, finance department, economic planning department, procurement department 
and ICT department). The proportionate sampling was used to distribute the sample among each stratum to ensure proportionally distribution of the sample according to the number of participants. This also enhance distribution representation and avoids bias in sampling. Lastly purposive sampling technique were used in selection of respondents.

\section{Data Collections Instruments}

This study adopted questionnaires as its main data collection tool. The questionnaires were used to collect data for the study. Each questionnaire was divided into sections namely: demographic information's of the respondents and influence of strategy formulation practice on performance of milling companies. Questionnaires with both closed ended and openended questions were used because they are easy to administer and are economical in terms of time and money (Dornyei \& Taguchi, 2009). Data collected through questionnaires are easier to analyze and interpret. The Likert scale type of questionnaire were employed to collect the data. This is because they are easy to complete and are unlikely to put off respondents.

\section{Data Analysis and Presentation}

Data collected from the field were organized and edited to remove any inconsistencies, repetitions or errors that can make analysis difficult. Cleaned data were coded to enable the responses to be grouped into various categories. Data were analyzed using both descriptive and inferential statistics. Descriptive statistics included; percentages, frequencies, means, standard deviations, maximum and minimum. Tables and bar charts were used to summarize responses for further analysis and to facilitate comparison. Inferentially data were analyzed using correlations and multiple regressions. It is used when the researcher wants to predict the value of a variable based on the value of two or more other variables.

Multiple regression models

$\mathbf{Y}=\boldsymbol{\beta}_{0}+\boldsymbol{\beta}_{1} \mathbf{X}_{1}+\varepsilon$

Equation 1

\section{Where:}

$X$ represent the independent variables $-\mathrm{x}_{1}$ represent strategy formulation practices

$Y$ represent the dependent variable (performance of milling companies)

$\beta_{0}$ is a constant when the performance of milling companies does not depend on the four variables being investigated.

$\beta_{1}$, are the coefficients of proportionality for the study variables respectively

Beta is the probability of Type II error in any hypothesis test.

$\varepsilon=$ Error term is created when the regression model does not fully represent the actual relationship between the independent variables and the dependent variables

\section{Research Findings and Discussions \\ Response Rate}

The study's response rate is presented in Table 3.

Table 3 Response Rate

\begin{tabular}{lll}
\hline Questionnaires & Frequency & Percentage \\
\hline Questionnaires returned & 76 & 88.4 \\
Unreturned questionnaires & 10 & 11.6 \\
Total & $\mathbf{8 6}$ & $\mathbf{1 0 0 . 0 0}$ \\
\hline
\end{tabular}


A total of 86 questionnaires were distributed, out of which 76 were duly filled and returned, resulting to a response rate of $88.4 \%$.

\section{Strategy Formulation Practice}

The study sought to determine the influence of strategy formulation practice and performance of milling companies in Kenya. Table 4 presents the study results.

\section{Table 4 Strategy Formulation Practice}

\begin{tabular}{|c|c|c|c|c|c|c|c|c|}
\hline Statements & & SA & A & UD & D & SD & Mean & Sd \\
\hline $\begin{array}{l}\text { 1. Your firm has deliberately set } \\
\text { its strategic direction in form of } \\
\text { vision statement }\end{array}$ & $\%$ & 32.9 & 51.3 & 3.9 & 2.6 & 9.2 & 3.96 & 1.148 \\
\hline $\begin{array}{l}\text { 2. Your firm has deliberately set } \\
\text { its strategic direction in form of } \\
\text { mission statement }\end{array}$ & $\%$ & $\begin{array}{l}17 \\
22.4\end{array}$ & 60.5 & 2.6 & 5.3 & 9.2 & 3.82 & 1.128 \\
\hline $\begin{array}{l}\text { 3. Internal environment } \\
\text { analysis is a top priority activity at } \\
\text { your firm }\end{array}$ & $\%$ & 17.1 & 61.8 & 7.9 & 2.6 & 10.5 & 3.72 & 1.114 \\
\hline $\begin{array}{l}\text { 4. Your firm analyzes } \\
\text { information about its external } \\
\text { environment to understand their } \\
\text { implications }\end{array}$ & $\%$ & 18.4 & 51.3 & 11.8 & 9.2 & 9.2 & 3.61 & 1.167 \\
\hline Total number (n) & 76 & & & & & & 3.78 & \\
\hline
\end{tabular}

Table 4 shows that $64(84.2 \%)$ of the respondents agreed with the statement that your firm has deliberately set its strategic direction in form of vision statement. However, $9(11.8 \%)$ of the respondents disagreed. Further the study findings showed in terms of means and standard deviation that your firm has deliberately set its strategic direction in form of vision statement (Mean=3.96., Std. dev=1.148). Also, 63(82.9\%) of the respondents agreed with the statement that your firm has deliberately set its strategic direction in form of mission statement. However, 11(14.5\%) of the respondents disagreed. Further the study findings showed in terms of means and standard deviation that your firm has deliberately set its strategic direction in form of mission statement (Mean=3.82., Std. dev=1.128).

Another, $60(78.9 \%)$ of the respondents agreed with the statement that internal environment analysis is a top priority activity at your firm. However, 10(13.2\%) of the respondents disagreed. Further the study findings showed in terms of means and standard deviation that internal environment analysis is a top priority activity at your firm (Mean=3.72, Std. dev=1.114). Finally, 53(69.7\%) of the respondents agreed with the statement that your firm analyzes information about its external environment to understand their implications. However, 14(18.4\%) of the respondents disagreed. Further the study findings showed in terms of means and standard deviation that your firm analyzes information about its external environment to understand their implications (Mean=3.61, Std. dev=1.167).

The study results also shows that strategy formulation practice has a positive influence on performance of milling companies in Kenya. This implies that the firm as deliberately set its 
strategic direction in form of vision statement. Also, has deliberately set its strategic direction in form of mission statement. Also, internal environment analysis is a top priority activity at your firm. Finally, firm analyzes information about its external environment to understand their implications.

The study results concur with Onijingin, (2017) who revealed that there were significant relationships between Competitive Behaviour and Corporate Performance. It also revealed a significant moderating effect of Competitive Capability on the relationship between Competitive Behaviour and Corporate Performance. The study results concur with Macharia, (2014) who found out that competition has really intensified in recent years and the company has adopted several strategies to respond to increased competition. These strategies include quality consistency, flexible pricing, product rationalization and branding.

\section{Correlation Analysis}

Pearson correlation analysis was carried out to show the strength and direction of the association between independent and dependent variables. Table 5 present the results. strategy formulation practice and performance of milling companies

Table 5 Multiple Correlation Analysis Results

\begin{tabular}{|l|l|l|l|}
\hline & & $\begin{array}{l}\text { Performance of } \\
\text { milling companies }\end{array}$ & $\begin{array}{l}\text { Strategy } \\
\text { formulation } \\
\text { practice }\end{array}$ \\
\hline $\begin{array}{l}\text { Performance of milling } \\
\text { companies }\end{array}$ & $\begin{array}{l}\text { Pearson } \\
\text { Correlation }\end{array}$ & 1 & \\
\cline { 2 - 4 } & Sig. (2-tailed) & & 1 \\
\hline $\begin{array}{l}\text { Strategy formulation } \\
\text { practice }\end{array}$ & $\begin{array}{l}\text { Pearson } \\
\text { Correlation }\end{array}$ & $.547^{* *}$ & \\
\cline { 2 - 4 } & Sig. (2-tailed) & .000 & \\
\hline
\end{tabular}

**. Correlation is significant at the 0.01 level (2-tailed).

The study findings in Table 5 indicated that strategy formulation practices and performance had a positive, strong and statistically significant correlation $(r=0.547 ; p<0.01)$.

\section{Regression Model Coefficients}

Regression model coefficients were run in order to use in the regression equation. The study results are presented in Table 6. 
Table 6 Regression Model Coefficients

\begin{tabular}{|l|l|l|l|l|l|}
\hline & \multicolumn{2}{|l|}{$\begin{array}{l}\text { Unstandardized } \\
\text { Coefficients }\end{array}$} & $\begin{array}{l}\text { Standardized } \\
\text { Coefficients }\end{array}$ & & \\
\cline { 1 - 6 } & B & $\begin{array}{l}\text { Std. } \\
\text { Error }\end{array}$ & Beta & $\mathrm{t}$ & Sig. \\
\hline (Constant) & .780 & .390 & & 2.002 & .049 \\
\hline Strategy formulation practices & .210 & .098 & .227 & 2.143 & .036 \\
\hline $\mathrm{R}^{2}$ & .495 & & & & \\
\hline F-statistic & $\begin{array}{l}17.394^{*} \\
* *\end{array}$ & & & & \\
\hline
\end{tabular}

The study results in Table 6 revealed that $\mathrm{R}^{2}$ was 0.495 implying that only $49.5 \%$ of the dependent variable variations could be explained by independent variables. The respondents F-statistics produced $(F=17.394)$ which was significant at $p=0.000$ thus confirming the fitness of the model. This implies that the multiple regression model was fit for the data. There was positive linear effect of strategy formulation practices on performance of milling companies in Kenya $\left(\beta_{1}=.210, p=0.036<0.05\right)$. This reveals that an increase in strategy formulation practices leads to increase in performance of milling companies in Kenya by 0.210 units.

\section{Summary, Conclusion and Recommendations \\ Summary of the Findings Strategy Formulation Practices}

The objective of the study was to determine the influence of strategy formulation practice on performance of milling companies in Kenya. The descriptive statistics showed that the firm as deliberately set its strategic direction in form of vision statement. Also, has deliberately set its strategic direction in form of mission statement. Also, internal environment analysis is a top priority activity at your firm. Finally, firm analyzes information about its external environment to understand their implications. The correlation results showed that there was a significant effect of strategy formulation practices on performance of milling companies in Kenya. This implies that the firm as deliberately set its strategic direction in form of vision statement. Also, has deliberately set its strategic direction in form of mission statement. Also, internal environment analysis is a top priority activity at your firm. Finally, firm analyzes information about its external environment to understand their implications.

\section{Conclusions of the Study}

The study concluded that strategy formulation practices have a positive and a significant influence on performance of milling companies in Kenya. The firm as deliberately set its strategic direction in form of vision statement. Also, has deliberately set its strategic direction in form of mission statement. Also, internal environment analysis is a top priority activity at your firm. Finally, firm analyzes information about its external environment to understand their implications.

\section{Recommendations of the Study}

The milling firms should deliberately set its strategic direction in form of vision statement this will always ensure that internal environment analysis is a top priority activity at the firm. 
The milling firms should allocate adequate resources, involve stakeholders during strategy implementation, operationalize strategies and always communicate comprehensively to all stakeholders during strategy execution in order for them to realize performance.

\section{Refference}

Afriyie, S., Duo, J., \& Musah, A. A. I. (2018). The nexus between innovation types and marketing performance of SMEs in an emerging economy: the mediating role of knowledge sharing. Journal of Economics, Management and Trade, 1-22.

Bolisani, E., \& Bratianu, C. (2017). Knowledge strategy planning: an integrated approach to manage uncertainty, turbulence, and dynamics. Journal of Knowledge Management.

Chen, M., \& Bowen, L. (2012). Strategic management in chinese manufacturing SMEs.

Hanssens, D. M., \& Pauwels, K. H. (2016). Demonstrating the value of marketing. Journal of Marketing, 80(6), 173-190.

Joyce, P. (2015). Strategic management in the public sector. Routledge.

Kinyua, J. K., Gakure, R., Gekara, M., \& Orwa, G. (2015). Effect of internal control environment on the financial performance of companies quoted in the Nairobi Securities Exchange. International Journal of Innovative Finance and Economics Research, 3(4), 2948.

Macharia, F. G. (2014). Strategic responses to environmental challenges by alliance ginneries Ltd in Tanzania (Doctoral dissertation, University of Nairobi).

Ngige, C. D. (2017). Strategic Planning and Productivity in Organizations: A Study of Selected SMEs in Anambra State. African Journal of Education, 3(4), 122.

Onijingin, K. (2017). Competitive dynamics and corporate performance of selected flour milling companies in Nigeria. An unpublished PhD thesis in Business Administration, Babcock University Ilicin-Remo, Ogun State, Nigeria.

Reeves, M., \& Haanaes, K. (2015). Your strategy needs a strategy: How to choose and execute the right approach. Harvard Business Review Press.

Tripathi, K. K., \& Jha, K. N. (2018). Determining success factors for a construction organization: A structural equation modeling approach. Journal of management in engineering, 34(1), 04017050.

Yong, J. Y., \& Mohd-Yusoff, Y. (2016). Studying the influence of strategic human resource competencies on the adoption of green human resource management practices. Industrial and Commercial Training. 